University of Wollongong

Research Online

Faculty of Business - Papers (Archive)

Faculty of Business and Law

$1-1-2016$

The effect of voluntary versus mandatory adoption of trading policies on the returns to insider trades

Millicent M. Chang

University of Western Australia, mchang@uow.edu.au

Marvin Wee

University of Western Australia

Follow this and additional works at: https://ro.uow.edu.au/buspapers

Part of the Business Commons

Research Online is the open access institutional repository for the University of Wollongong. For further information contact the UOW Library: research-pubs@uow.edu.au 


\title{
The effect of voluntary versus mandatory adoption of trading policies on the returns to insider trades
}

\author{
Abstract \\ An insider trading policy is a critical aspect of a firm's internal governance which ensures the \\ maintenance of corporate transparency. We examine the effect of trading policies on the returns to trades \\ by corporate insiders over two periods: one where the adoption of a policy is voluntary and another where \\ it is mandatory. In the former, we find that the requirement to notify the firm prior to trading does not \\ result in lower trade returns on days outside the permitted trading windows. Where adoption of a policy is \\ mandatory, trade returns made during the restricted windows are higher and the requirement to notify \\ prior to trading significantly reduces these returns. The mandatory disclosure of a trading policy is \\ effective in reducing returns from insider trading, suggesting improved investor confidence through \\ greater transparency.

\section{Disciplines} \\ Business

\section{Publication Details} \\ Chang, M. \& Wee, M. (2016). The effect of voluntary versus mandatory adoption of trading policies on the \\ returns to insider trades. Pacific Basin Finance Journal, 38 76-87.
}




\title{
The Effect of Voluntary versus Mandatory Adoption of Trading Policies on the Returns to
}

\section{Insider Trades}

\author{
Millicent Chang \\ UWA Business School \\ Marvin Wee* \\ UWA Business School
}

\begin{abstract}
An insider trading policy is a critical aspect of a firm's internal governance which ensures the maintenance of corporate transparency. We examine the effect of trading policies on the returns to trades by corporate insiders over two periods: one where the adoption of a policy is voluntary and another where adoption is mandatory. In the former, we find that the requirement to notify the firm prior to trading does not result in lower trade returns on days outside the permitted trading windows. Where adoption of a policy is mandatory, trade returns made during the restricted windows are higher and the requirement to notify prior to trading significantly reduces these returns. The mandatory disclosure of a trading policy is effective in reducing returns from insider trading, suggesting improved investor confidence through greater transparency.
\end{abstract}

JEL classification: G14, G34

Keywords: $\quad$ Insider trading policy, permitted trading periods, restricted trading periods, trading returns, insider holdings, corporate governance

* Corresponding author: Marvin Wee, UWA Business School, M250, 35 Stirling Highway, Crawley, Western Australia 6009. Email: Marvin.Wee@uwa.edu.au Tel: +61 864885860.

We thank participants at the Accounting and Finance Association of Australia and New Zealand conference, and at the Australian National University Accounting and Business Information Systems Research School research seminar for their helpful comments. We acknowledge the excellent research assistance provided by Yi Lin Lim and Sirca for providing the data required. 


\title{
Insider Trades
}

\begin{abstract}
An insider trading policy is a critical aspect of a firm's internal governance which ensures the maintenance of corporate transparency. We examine the effect of trading policies on the returns to trades by corporate insiders over two periods: one where the adoption of a policy is voluntary and another where adoption is mandatory. In the former, we find that the requirement to notify the firm prior to trading does not result in lower trade returns on days outside the permitted trading windows. Where adoption of a policy is mandatory, trade returns made during the restricted windows are higher and the requirement to notify prior to trading significantly reduces these returns. The mandatory disclosure of a trading policy is effective in reducing returns from insider trading, suggesting improved investor confidence through greater transparency.
\end{abstract}

JEL classification: G14, G34

Keywords: $\quad$ Insider trading policy, permitted trading periods, restricted trading periods, trading returns, insider holdings, corporate governance 


\section{The Effect of Voluntary versus Mandatory Adoption of Trading Policies on the Returns to Insider Trades}

\section{Introduction}

A firm's insider trading policy is an integral part of the overall firm governance system describing how a company is directed and managed such that objectives are met, risks are monitored and performance maximised. The role of a trading policy within the governance framework is to ensure and promote ethical and responsible decision making by insiders so that investor confidence is preserved and investor protection maintained. Furthermore, it provides transparency around policies surrounding insider activities, in particular restrictions on trading. If insider trading is viewed as an agency cost because private benefits can be extracted at the expense of other shareholders (Bebchuk and Fried 2003), an effective governance system can be expected to reduce this cost by active monitoring of insiders' trading activities (Bettis, Coles and Lemmon 2000).

Self-imposed trading policies work in conjunction with existing country level insider trading regulation which is enforced by market regulators. Lee, Lemmon, Li and Sequiera (2014) find that firm-imposed voluntary restrictions on insider trading activities are effective in reducing the exploitation of private benefits. In this study, we apply a micro approach to investigate the effect of investor protection (under the umbrella of corporate governance) on rent extraction via insider trading. Investor protection is proxied by a firm's trading policy under two regimes of mandatory and voluntary disclosure. We examine how a firm-imposed trading policy affects the returns to insider trades, when the trades are conducted in periods demarcated as "blackout periods" or 
"permitted periods" in both the voluntary and mandatory disclosure environments. In the accounting and finance literature and regulation, disclosure has been assumed to be a device which reduces information asymmetry, leading to less potential for opportunism. The regulation around the timely disclosure of insider trades is one example of this assumption. Huddart, Hughes and Levine (2001) also provide theoretical support by showing that prompt disclosure of insider trades reduces returns associated with them.

Mandatory disclosure of trading policies is expected to result in a better information environment because Huddart et al. (2001) show that the disclosure accelerates price discovery and reduces returns to trades. Corporate information transparency has been found to be negatively related to the number of insider purchase and sale transactions and their profitability ( $\mathrm{Gu}$ and $\mathrm{Li}, 2012)$. However, in their investigation of Rule 10b5-1 trading plans in the US, Henderson, Jagolinzer and Muller (2015) show that voluntary disclosure increases insider trading returns due to the legal cover provided by the disclosure. That is, the voluntary disclosure generated protection for opportunistic trading. The same could apply with the mandatory disclosure of trading policies where insiders trade opportunistically for higher returns and escape scrutiny because of a disclosed restrictive trading policy. We exploit this tension in the literature on mandatory disclosure of insider trading policies

Prior studies, including Anand and Beny (2007), Gompers, Ishii and Metrick (2003) and Cremers and Nair (2005), show the effects of good corporate governance on firm value. Directly relevant to this study are the findings that strong corporate governance reduces returns from insider trading (Chang, Hillman and Watson 2005; Fidrmuc, Goergen and Renneboog 2006; Jagolinzer, 
Larcker and Taylor 2011; Ravina and Sapienza 2010). Fidrmuc, Goergen and Renneboog (2006) use block monitoring to proxy for governance, Chang, Hillman and Watson (2005) use aspects of the board, Ravina and Sapienza (2010) employ Gompers et al.'s (2003) Governance Index and Jagolinzer, Larcker and Taylor (2011) apply the general counsel's approval. In contrast, using shareholder protection, Fidrmuc, Korczak and Korczak (2013) find a positive correlation between country level shareholder protection and post insider trade abnormal returns, arguing that their results support the information content hypothesis.

One contribution of our study to the existing literature is the investigation across two distinct years: the calendar year 2007 where disclosure of a trading policy was voluntary, though recommended and 2013 where it was mandatory. ${ }^{1}$ It is expected that the requirement to disclose a trading policy alters the trading habits of insiders and the resultant returns to their trades. For example, Brochet (2010) compares the information content of insider trades before and after the Sarbanes-Oxley Act 2002 (SOX) where SOX required the reporting of trades within two business days and greater scrutiny of insider activities. Post SOX, insider purchase filings are accompanied by higher abnormal returns and trading volume while for insider sales, the returns are lower. Jagolinzer, Larcker and Taylor (2011) examine the role of the general counsel who was responsible for enforcing corporate governance within a firm. Trades requiring general counsel approval have lower returns and are less informative about future firm operations.

\footnotetext{
${ }^{1}$ The Australian Securities Exchange Corporate Governance Council (ASXCGC) released its Principles of Good Corporate Governance and Best Practice Recommendations which included ten core principles and guidance on implementation in the form of best practice recommendations. Firms were required to disclose in the annual report the extent to which the best practice recommendations were observed and, if recommendations were not adhered to, the reasons for not doing so. Principle 3 of the Recommendations is relevant to trading policies and this study because it discusses the need for integrity among those who influence company strategy and financial performance. It also actively promotes ethical and responsible decision making. In particular, Recommendation 3.2 refers to the establishment of a policy concerning trading in company securities by directors, senior executives and employees and the disclosure of such a policy.
} 
Our study also differs from prior work as we examine a range of items in the firm's insider trading policy. Monitoring of trading activities is conducted via items within the policy such as timing restrictions on trades and notification prior to trading. In contrast to studies that have studied the influence of certain aspects of trading policy (see for example, Bettis, Coles and Lemmon 2000; Hillier and Marshall 2002; Jagolinzer, Larcker and Taylor 2011), we construct proxies that allows us to consider the combined effect of trading policy items on the information environment. We deliberate how these trading policy items influence the firm's information environment by estimated trade returns.

The composition of reported insider trades differs between countries due to the various definitions of insider: that is, parties who are required to report changes in their shareholding. In the U.S., corporate insiders are defined as company officers, directors and any beneficial owners of more than ten percent of a class of the company's equity securities (equivalent to substantial shareholders in Australia) while in Australia, the definition is restricted to company directors, being the parties who are required to disclose under s205G of the Corporations Act (2001). This important difference means that insider trades examined in Australia do not include those by large shareholders which may have different motivations for trading. Another important difference between the Australian and US institutional setting is the absence of the "short swing" rule (i.e., Section 16(b) of the Securities and Exchange Act of 1934) where insiders are penalised for profits earned on trades made fewer than 180 days after prior trades. Because of this, the use of a more prescriptive insider trading policy may signal greater emphasis placed by the firm on corporate governance and monitoring. 
Our results indicate that the number of items prescribed in firm trading policy has increased over the two periods examined. Only 7\% of the firms in our 2013 sample did not have a restricted trading window, compared to $52 \%$ in 2007. On average, a firm's trading policy covers four of the nine categories identified in 2007 and contains just over six categories in 2013. We also find in firms with greater analyst following and active trading by insiders, policies are more specific (i.e., have more categories), suggesting they were developed to instil investor confidence and/or to monitor trading activity.

We find returns to insiders are higher when they trade in the restricted trading windows, inferring that insiders profit from information that they are privy to during those times. Within firms that impose blackout periods, the returns to insiders are lower when prior notification of trading is required. The effects of the prior notification requirement are evident and effective in 2013 where the adoption of policies is mandatory.

The rest of the study is structured as follows: Section 2 provides the institutional and regulatory background while the hypotheses are discussed in Section 3. In Section 4, we discuss the sample used, the research method and provide the descriptive statistics. The results are presented and discussed in Section 5 and Section 6 concludes the study.

\section{Background: Institutional and regulatory}


In Australia, corporate insiders are required to report any changes to their shareholdings to the Australian Securities Exchange (ASX) in a timely manner. ${ }^{2}$ At present, s205G of the Corporations Act requires directors to notify the securities exchange of a change in holdings within 14 days while ASX Listing Rule 3.19A requires notification within five business days. Corporate insiders can trade on information as long as such information is generally available to other market participants and a reasonable person would not expect the information to impact materially on the price or value of shares. In addition, in accordance with s.300 (11) of the Corporations Act, corporate insiders must disclose their end of financial year holdings in the Annual Report.

The governance around firm trading policy is administered by the ASX Corporate Governance Council (ASXCGC). Within the ASXCGC's Principles and Recommendations, it defines corporate governance as "the system by which companies are directed and managed" (p. 3). Of the ten core principles, Principle 3 discusses the need for integrity among those who influence company strategy and financial performance and it actively promotes ethical and responsible decision making. In particular, Recommendation 3.2 refers to the establishment of a policy concerning trading in company securities by directors, senior executives and employees ("designated officers") and the disclosure of such a policy. This recommendation was deleted with the implementation of ASX Listing Rules 12.9 to 12.12, effective from $1^{\text {st }}$ January 2011. Specifically, ASX Listing Rule 12.9 requires listed firms to have and disclose their trading policy in accordance with ASX Listing Rule 12.12. According to ASX Listing Rule 12.12, a trading

\footnotetext{
2 The term "insiders" here refers to company directors.
} 
policy should, at a minimum, contain the following: closed period, ${ }^{3}$ trading restrictions that apply to key management personnel, any trading not covered by the trading policy, any exceptional circumstances when management may be allowed to trade during a restricted period with prior written clearance, and the procedures for obtaining such prior written clearance.

\section{Hypotheses}

\subsection{Trading policy restrictions and insider trade returns}

The controversies around insider trading can be generally classified into rent extraction by insiders and improvement in the information environment via the information contained within trades. With respect to rent extraction, Ausubel (1990), Fishman and Hagerty (1992) and others maintain that insider trading transfers wealth from uninformed investors to informed insiders such that information efficiency and liquidity are adversely affected. On the other hand, Manne (1966) and Carlton and Fischel (1983) assert its informational benefits where such trading accelerates the flow of private information into share prices. Therefore, the net effect of insider trading on the information environment would depend on the aggregate of the cost of rent extraction and the benefit of information content. Our study examines this effect in both voluntary and mandatory settings. If insider trading is a mechanism for rent extraction, then improved shareholder protection via more restrictive trading policies will result in lower returns following insider trades (Fidrmuc et al. (2013) refer to this effect as the monitoring hypothesis). On the other hand, if it represents a channel for private information to be incorporated into price, trading policies may not affect the returns to trades. This is because the policies have created an information environment where information is reflected in prices such that there are no excess

\footnotetext{
${ }^{3}$ The closed period refers to the time periods when a firm's key management personnel are prohibited from trading in the firm's securities.
} 
returns to trades. However, there could be another scenario where trading policies are overly restrictive, resulting in higher returns to trades, due to inefficient prices.

Much of the work done on the effect of insider trading policies has been limited to timing restrictions on trades. For example, Bettis, Coles and Lemmon (2000) find 78 percent of firms in their sample had explicit blackout periods which resulted in reduced insider trading and narrower spread. As a result, trades outside the blackout period became more profitable than those within the prohibited periods. Jagolinzer et al. (2011) also report higher returns when insiders traded within the restricted windows. In contrast, while trading bans on London Stock Exchange firms affect the timing of trades, their performance remains unchanged (Hillier and Marshall, 2002). Lee et al. (2014) investigate voluntary restrictions on insider trading generally and found them effective in reducing insider exploitation of their private information. However, Lee et al. (2014) did not specifically examine whether these trades were conducted within restricted windows. Trading restrictions are expected to reduce insider returns from trading because Roulstone (2003) and Denis and $\mathrm{Xu}$ (2013) show that trading restrictions are accompanied by higher compensation and greater use of incentive compensation. One side effect of trading restrictions however is higher corporate risk taking (Yusnadi, 2014).

Based on Bettis et al. (2000) and Jagolinzer et al. (2011), we predict that when insiders choose to trade within restricted windows, they do so opportunistically in order extract rents from their private information. Therefore, the returns are expected to be higher compared to trading during other times. 
H1: Insiders earn higher returns from trades made in the restricted windows, compared to trades at other times.

Jagolinzer et al. (2011) examine the impact of the general counsel who was responsible for shaping internal governance within the firm. They report that profits are lower when general council approval is required prior to trading. While Beny (2005) reports a negative relationship between the quality of insider trading law and returns, Bris (2005) shows that enforcement of insider trading laws results in greater incidences of insider trading and higher returns from such trading. Given that effective corporate governance mechanisms can reduce insiders' ability to extract rents from other shareholders (Chang et al. 2005; Fidrmuc et al. 2006), we propose that the requirement to notify the firm prior to trading is likely to reduce the insiders' profit when they trade.

H2: Insiders in firms with the requirement to notify the firm prior to trading earn lower returns on trades in the restricted windows, compared with insiders in firms without requirements to notify prior to trading.

\section{Sample and method}

The regulatory requirements relating to the trading policies of Australian firms can be roughly segmented into two time periods. We consider the years 2002 to 2010 as part of the voluntary period. During this period, firms are required to provide a statement in their annual report disclosing the extent to which they have complied with the ASXCGC Recommendations and, for firms that have not adopted all items, to provide the reasons for not adopting those items. The 
second period, 2011 onwards, represents the time when the adoption of an insider trading policy is mandatory. ${ }^{4}$ The ASX recommends a trading ban on insiders between the end of the firm's financial year and the release of its annual earnings report and many firms impose this restriction on their insiders. These blackout windows are around periods where information asymmetry is higher and where insiders potentially are privy to price sensitive information.

For each firm in the S\&P/ASX300 index in 2007 and 2013 period, we source the trading policy from either the annual report or corporate website. The sample consists of 566 trading policy firm-years. Details about each firm's trading policy were collected and based on the items disclosed in the trading policy, nine categories were identified. ${ }^{5}$ Items disclosed by firms were placed into one of these categories. Therefore, more than one item could fall under the same category. The collection of items from each firm's trading policy identified 251 unique disclosure items. The list was reduced to 239 items, where items were disclosed by more than one firm in the sample. The appendix provides examples of items disclosed and their designated categories.

The category disclosure score (ITP_Score) requires at least one item in a category to be disclosed to attain a value of 1 . Otherwise, the score for that category is 0 . The scores of each category were aggregated to arrive at a total score for each firm year. Therefore, the ITP_Score's minimum and maximum are 0 and 9 respectively and equal weighting is given to each category. The nine categories are as follows:

\footnotetext{
${ }^{4}$ The second edition of the policy was released in August 2007.

5 With the exception of the ASXCGC's recommendation on specification of discretion to trade in certain circumstances, the nine categories account for seven of the eight recommendations.
} 
1) Definition of information on which insiders are not allowed to trade and reinforcement of regulation (def_info);

2) Shares and financial products the policy refers to (app_itp);

3) Restrictions on short term dealing (st_dealing);

4) Awareness and monitoring of compliance with policy (comp_policy);

5) Details of director shareholding requirements (dir_shh);

6) Reporting of trading (report_trading);

7) Prior notification/approval of trading (prior_notification);

8) Windows in which directors cannot trade (dir_cannottrade); and

9) Windows in which directors can trade (dir_cantrade).

Data on director trading were collected for all firms in the sample. Trade data including date of trade, date of report of trade, name of director, number of shares traded, value of shares traded and reasons for the trade were obtained from Morningstar DatAnalysis Premium while firm characteristic data were sourced from Morningstar DatAnalysis Premium and I/B/E/S. Share price data was sourced from CRD.

We examine if a relationship exists between the adoption and restrictiveness of the insider trading policy, and the characteristics of the firm using the following logistic regression:

$$
\operatorname{Pr}(\text { PriorNotification }=1)=\frac{1}{1+e^{-\beta X}},(1)
$$

where, 


$$
X_{i}=\alpha_{0}+\alpha_{1} \text { Analysts }_{i}+\alpha_{2} \text { MVE }_{i}+\alpha_{3} M B_{i}+\alpha_{4} \text { Count_Purchases }_{i}+\alpha_{5} \text { Count_Sales }_{i}+e_{i, t}
$$

PriorNotification $=$ Dummy variable that takes on the value of one if the firm has a requirement that insiders notify the firm prior to trading and zero otherwise;

Analysts $\quad=$ the natural logarithm of the number of analysts following the firm during the year; ${ }^{6}$

MVE = the natural logarithm of the market capitalisation at financial year end;

$M B \quad=$ the market to book ratio at financial year end; and

Count_Purchases $=$ the number of insider purchases made during the financial year.

Count_Sales $\quad=$ the number of insider purchases made during the financial year.

In a different specification of the above model, we replace the binary dependent variable with a continuous variable measuring the prescriptiveness of the insider trading policy in the firm. ITP_Score is the score based on the number of trading policy categories disclosed as described above.

To identify trades to be included in our analysis, the following requirements were used to arrive at the final sample: the trade must be an on-market trade, the interest held by the director must be direct, the trade is not an initial or final change in shareholdings and the trades must not be due to exercise of stock options, bonus issues and rights issues. These requirements reduced the sample to 1,458 trades in 2007 and 2,710 trades in 2013 .

\footnotetext{
${ }^{6}$ We add one to the number of analysts for firms that have no analyst coverage.
} 
We apply the standard event study method where the event is the reported date of a change in director interest. Cumulative abnormal returns $(C A R)$ associated with these trades were measured as market model adjusted returns over five, 10, and 20 days after the trade date. Therefore, $C A R$ is estimated as:

$$
C A R_{i, t}=C R_{i, t}-\beta_{\mathrm{i}} \times C R_{\mathrm{Mi}, t}
$$

where $C A R_{\mathrm{i}, t+k}$ is the cumulative market adjusted return of share $i$ on day $t+k, C R_{i, t}$ is the ratio of the price of share $i$ on day $t+k$ relative to its price at the start of the period on day $t$ and $C R_{\mathrm{M} i, t}$ is the analogous price relative for the market, proxied by the All Ordinaries Accumulation Index. Beta for the stock trade is estimated using the returns of the stock and market in the estimation period of $(-110,-10)$ where day 0 is the trade date.

We use Ordinary Least Squares regression with robust standard errors to analyse the relation between returns to insider trades and the individual firm's trading policy, while controlling for trade and firm characteristics. The following equation was used to test the relationship ${ }^{7}$ :

$$
\begin{aligned}
\text { CAR }_{i, t} & =\alpha+\beta_{1} \text { TxnValue }_{i, t}+\beta_{2} \text { RelVol }_{i, t}+\beta_{3} \text { Lag }_{i, t}+\beta_{4} \text { MVE }_{i, t} \\
& +\beta_{5} \text { Analysts }_{i, t}+\beta_{6} \text { MB }_{i, t}+\beta_{7} \text { Unclassified }_{i, t}+\beta_{8} \text { PriorNotification }_{i, t} \\
& +\beta_{9} \text { Unclassified }_{i, t} \times \text { PriorNotification }_{i, t}+\beta_{10} \text { Blackout }_{i, t} \\
& +\beta_{11} \text { Blackout }_{i, t} \times \text { PriorNotification }_{i, t}+e_{i, t}
\end{aligned}
$$

\footnotetext{
${ }^{7}$ The return to sales was multiplied by -1 to allow a combination of the returns to purchases with the returns to sales.
} 
Where:

CAR = cumulative market-adjusted returns measured over five, 10, 20 day windows around the trade date;

TxnValue $\quad=$ the number of shares traded multiplied by the last trade price on the trade date;

RelVol = transaction volume divided by the number of shares outstanding at financial year end;

Lag $\quad=$ the lag between the trade date and the date the trade is reported to the Exchange;

Unclassified = a dummy variable that takes on the value of one if the trade was made in period where the firm has not specified if it is a restricted or permitted trading period and zero otherwise; and

Blackout = a dummy variable that takes on the value of one if the trade was made in a period where the firm has specified that it is a restricted trading period and zero otherwise.

The variables Unclassified and Blackout allow us to examine the returns to trades during the various trading windows. In addition, the variable PriorNotification permits us to inspect if the requirement to notify prior to trading mitigates the returns during the various trading windows. We control for the size of transaction (both TxnValue and RelVol), the lag between trade and report dates $(L A G)$ which is indicative of the insider's intention to conceal her information advantage, the growth prospects proxied by the market to book ratio $(M B)$, and the size of the firm (MVE). 


\section{Results}

\subsection{Descriptive statistics}

There are 270 firms in the sample for 2007 and 296 firms for 2013 . Of these, only 125 firms appear in both time period samples. The high drop off appears to be due to smaller firms not surviving until 2013. Table 1 Panel A shows the proportion of firms in our sample that includes the various categories of items in their trading policy over our sample period. Of the 566 firmyears, there are 18 firm-years where a trading policy is not disclosed. These firm-year observations are from 2007 and as expected, all firms disclose a policy in 2013. Compared to the rate of $40 \%$ in 2000 and 2001 from Chang et al (2005), there has been an substantial increase in the number of firms with disclosed trading policies.

\section{[Insert Table 1 about here]}

When looking at the nine separate categories, we find $76 \%$ of the firms in 2007 have policies defining the information on which insiders are not allowed to trade (Def_info), with the number increasing to $94 \%$ in 2013. Approximately 54\% of the firms in 2007 and $68 \%$ in 2013, have a requirement for insiders to notify the firm prior to trading (PriorNotification) in the firm's shares and financial products. In both sample years, less than half of the firms stipulate the windows in which insiders are permitted to trade (Dir_cantrade). There is a substantial increase in the number of firms that refer to the blackout window in their policy (Dir_cannottrade), increasing from $48 \%$ in 2007 to $92 \%$ of the firms in 2013. Not surprisingly, ITP_Score based on the average number of categories the firm includes in its trading policy increased from 3.7 in 2007 to 5.4 in 2013. 
Table 1 Panel B shows that the firms in our two sample periods are similar when comparing the market value of equity $(M V E)$, amount of total assets $(T A)$ and the market to book ratio $(M B)$. However, there is a significant increase in the analyst coverage (Analysts) from an average of 7.9 in 2007 to 10.6 in 2013. Table 1 Panel C shows the size of insider transactions has also increased in terms of relative volume traded (RelVol). However, the transaction value (TxnValue) and the lag between the trade and report dates ( $\mathrm{Lag}$ ) have not changed across the two years.

\subsection{Relationship between insider trading policy, firm characteristics and frequency of insider trading}

Table 2 presents the OLS and logistic regression models for the two variables, and ITP_Score (Model 1) and PriorNotification (Model 2), on the characteristics of the firms. The models show that firms with higher analyst following (Analysts) are likely to have more restrictive policies and require insiders to notify the firm prior to trading. However, this effect is only observed in 2007 (the voluntary period) and not in 2013 when a trading policy was mandatory. The number of purchases is positively associated with the number of items in the policy in both 2007 and 2013, but not the number of sales. Interestingly, the size of the firm does not affect the firm's policy.

During the voluntary period, analyst monitoring of firms and frequent trading by insiders are found to put pressure on firms to disclose more restrictive policies to mitigate the reduction in investor confidence and firm reputation loss when insider trading occurs in these firms (Ramsay and Shekhar, 2012). In comparison, when these firms are required to disclose a trading policy (which at a minimum should contain details on closed periods, trading restrictions, trading 
outside the policy, exceptional cases when trading is allowed and written clearance for such trading), only firms with growth opportunities and frequent insider trading continue to invest in more restrictive policies. It is also not surprising that analyst following has no influence on the likelihood of prior notification, given that it is now a requirement under the mandatory policy.

[Insert Table 2 about here]

In Table 3, we present the regressions of the frequency of insider purchases and sales on the insider trading policy score and firm characteristics. The conclusions from this specification of the relation are generally consistent with those drawn from Table 2 . In the voluntary period, firms with higher ITP_Score have more insider purchases but not sales. This suggests that firms may set in place, in the voluntary period, more restrictive policies to ensure that insiders are not engaged in misconduct or are perceived to be doing so. However, the inclusions of requirements such as having the directors inform the firm prior to trading (PriorNotification) and stipulating windows where directors can trade (Dir_cantrade) or cannot trade (Dir_cannottrade) do not affect the number of insider purchases. The variable Dir_cannottrade has a negative relationship (significant at the $10 \%$ level) with the number of sales, indicating that directors are less likely to sell shares in the firm when there are restrictions with regard to when they cannot trade.

Insiders are known to be contrarian traders; trading in anticipation of future price reversals (Seyhun, 1992) and trading contrary to the market's overreaction to past performance (Rozeff and Zaman, 1998). The coefficients on MB indicate insiders' contrarian behaviour and are consistent with trading against misvaluation, as reported in Piotroski and Roulstone (2005). That 
is, insiders trades are negatively related to the market to book ratio (as shown in Table 3) and trade returns are positively related to the market to book ratio (shown in Table 5). Comparing purchases and sales in 2007 and 2013, the contrarian effect reduces in the mandatory period, as a consequence of more efficient prices in the improved information environment. We repeat the analysis (unreported) for a common sample of firms in 2007 and 2013 and find similar results.

The relationship between the ITP_Score and the number of insider purchases are not evident in 2013 (see Panel B Models 1 and 3). However, the inclusion of the item Dir_cannottrade has a positive and significant relationship with the number of insider sales and purchases (see Panel B Models 2 and 4). This suggests, when firms are required to disclose a trading policy, some items within the policy (i.e., PriorNotification and Dir_cantrade) are commonly adopted and hence are likely to be perceived as less effective as governance tools.

[Insert Table 3 about here]

\subsection{The effect of trading restrictions on insider trading profits}

Table 4 shows the frequency of and returns to trading within and outside of the restricted (blackout) and permitted trading periods. The cumulative abnormal returns are estimated over five, 10 and 20 days after the trade date using the market model. Panel A shows the breakdown of the trades made in 2007. The average returns are small and range from $-0.05 \%$ to $0.56 \%$ from five to 20 days after the trade. Of the 1,458 trades, there is only a small number of trades made during the blackout window $(\mathrm{n}=5)$ (henceforth, blackout trades) and a substantially greater 
number of trades made during the unclassified $^{8}$ window $(n=1,091)$ (henceforth, unclassified trades). The returns to unclassified trades are consistently larger than the returns to the trades made during the permitted windows (henceforth, permitted trades), regardless of the windows used to estimate the returns. The difference is statistically significant when returns is estimated using the wider window of 20 days.

[Insert Table 4 about here]

Panel B shows the returns to the trades made in 2013. About ten percent of the insider trades are not compliant with firm imposed trade timing restrictions. ${ }^{9}$ The magnitude of the returns to the unclassified trades is smaller than the returns to the blackout and permitted trades. Consistent with our expectations, the returns to the blackout trades are larger than the unclassified and permitted trades. The returns are significantly larger when returns are measured over a shorter horizon of between five and 10 days after the trade.

In general, the mandatory disclosure policy has been effective because trade returns in two out of the three windows are lower in 2013 compared to 2007. However, a concern is the nine percent of trades in 2013 conducted in the blackout period and the $71 \%$ of trades in the unclassified windows. The latter suggest that there is still room for improvement in the details of the firm's disclosed trading policy. The results in Panel A and B also suggest some of the unclassified

\footnotetext{
${ }^{8}$ Unclassified trades are trades neither in the blackout nor permitted windows.

${ }^{9}$ However we are not aware if these insiders obtained special permission to trade in the restricted periods.
} 
trades made in 2007 are likely to be made close to information events and would be labelled as blackout trades if we impose the windows known in 2013 on the earlier sample period. ${ }^{10}$

Table 5 presents the results of the regression of cumulative abnormal returns on trading window indicator variables and the prior notification requirement indicator variable. We include the notification requirement indicator variable to determine whether there were differences in returns when firms had such an aspect of the policy in place. This allows us to test for an effect similar to Jagolinzer et al.'s (2012) general counsel permission to trade.

Panels A and B show the regression model results for purchases and sales, respectively, made in 2007. As there are a small number of blackout trades and these occur only in firms with policies that require insiders to notify before trading, the Blackout indicator could not be used for this model. The returns to unclassified trades are higher than the returns to permitted trades $(t$-stat. of 1.57 and 2.16) when returns is measured using the five day window. However, the coefficient on the indicator variable Unclassified is not significant when returns are measured over the longer horizon. The coefficients on the interaction term Unclassified*PriorNotification in all models for purchases and sales are negative suggesting the prior notification requirement has a mitigating effect on returns. However, the coefficients are significant at the conventional levels for sales only when returns is measured using the five and 10 day windows.

[Insert Table 5 about here]

\footnotetext{
${ }^{10}$ We examined the unclassified trades in 2007 by imposing the windows known in 2013. However, the results (not tabulated) do not support the findings for 2013. This is likely due to the relatively small number of firms that are in both year samples, and that these firms are typically larger in size and are associated with better corporate governance.
} 
The regression results for 2013 are presented in Panels C and D, and the conclusions differ from those for 2007. Models 1, 2 and 3 show that returns to purchases made during blackout periods are significantly higher than the returns to permitted trades ( $t$-stat. of 1.81, 2.95 and 2.66 respectively), supporting Hypothesis H1. The coefficients on the interaction term Blackout*PriorNotification in all three models for both purchases and sales are negative though only statistically significant in models 2 and 3 ( $t$-stat. of -1.74 and -3.06 ). Overall, hypothesis $\mathrm{H} 2$ is supported with the prior notification requirement reducing insider trade returns. The findings are consistent with Jagolinzer et al. (2012) where trading profits in restricted trade windows are significantly lower when general counsel approval to trade is required.

\section{Conclusions}

We examine the relation between firm-imposed insider trading policy and the returns associated with insider trades. A firm's insider trading policy explains and directs the behaviour of insiders when they trade in their own firm's shares. Such policies are important because they provide confidence to investors that insiders are not abusing their position of privilege within the firm by extracting private benefits to the detriment of other shareholders. The trading policy is expected to affect the firm's information environment and the behaviour of insiders when they trade due to greater transparency of the specific contents of the trading policy. This is specifically due to the requirement to obtain permission before trading can occur, timely reporting of trades after trading has occurred and restrictions on when trading can occur. 
Our results show that the introduction of Best Practice Recommendations by the ASX Corporate Governance Council (voluntary disclosure period) has seen many firms choose to adopt and disclose their insider trading policies. Following the implementation of ASX Listing Rule 12.12 where the requirement is for all firms to adopt a trading policy, this has led to increases in some of the details disclosed within the policies. During the voluntary period, firms with more analyst following provided more detailed policies, measured by the number of categories and items disclosed. We also find firms with more frequent trading by insiders with more detailed policies, perhaps to mitigate the likelihood and perception of insider misconduct.

When the returns to trades conducted within and outside the restricted windows were compared, the returns in the former were generally higher. Not all firms impose these additional restrictions on the timing of insider trades and it appears that these restrictions were ineffective and noncompliant insiders benefited more from their trades. However when we also included the prior notification requirement, the returns to these trades decreased, showing that the notification requirement was effective in reducing the extraction of private benefits.

Our findings indicate that a firm's insider trading policy is an important and effective governance mechanism to reduce the extraction of private benefits of control by affecting the firm's information environment. Its development should be further encouraged, as seen from the mandatory requirement for listed firms to disclose a trading policy as of January 2011, resulting in a reduction in insider trade returns. Our findings provide some support for prescriptive rules on insider trading policy, over a principles-based approach. It appears that, within the mandatory period, firms are not simply ticking the boxes. Rather there is effective adoption and disclosure 
of firm specific insider trading policies resulting in a change in insider trading behaviour and increased investor confidence. However, there is room for improvement because blackout period trades still exist. The effects of various characteristics of a trading policy on a firm's information environment should be better understood together with its effect on insider trading behaviour. It is possible that the reaction to an insider's trade depends not only on the size of the transactions but also its timing within the firm's financial year. 


\section{References}

Anand, A. I., and L. N. Beny, 2007. Why do firms adopt insider trading policies? Evidence from Canadian firms(bepress).

Bebchuk, L. A., and J. M. Fried, 2003. Executive Compensation as an Agency Problem, Journal of Economic Perspectives 17, 71-92.

Bettis, J. C., J. L. Coles, and M. L. Lemmon, 2000. Corporate policies restricting trading by insiders, Journal of financial economics 57, 191-220.

Brochet, F., 2010. Information Content of Insider Trades before and after the Sarbanes-Oxley Act, Accounting Review 85, 419-446.

Chang, M., R. Hillman, and I. Watson, 2005. Are corporate governance mechanisms effective in reducing insider trading profits?, Company and Securities Law Journal 23, 165-180.

Cremers, K., and V. B. Nair, 2005. Governance mechanisms and equity prices, The Journal of Finance 60, 2859-2894.

Fidrmuc, J. P., M. Goergen, and L. Renneboog, 2006. Insider trading, news releases, and ownership concentration, The Journal of Finance 61, 2931-2973.

Gompers, P., J. Ishii, and A. Metrick, 2003. Corporate governance and equity prices, The Quarterly Journal of Economics 118, 107-156.

Hillier, D., and A. P. Marshall, 2002. Are Trading Bans Effective? Exchange Regulation and Corporate Insider Transactions around Earnings Announcements, Journal of Corporate Finance 8, 393-410.

Jagolinzer, A. D., D. F. Larcker, and D. J. Taylor, 2011. Corporate Governance and the Information Content of Insider Trades, Journal of Accounting Research 49, 1249-1274.

Ravina, E., and P. Sapienza, 2010. What do independent directors know? Evidence from their trading, Review of Financial Studies 23, 962-1003. 


\section{Table 1}

Firm characteristics and insider trading policy items for S\&P ASX300 firms

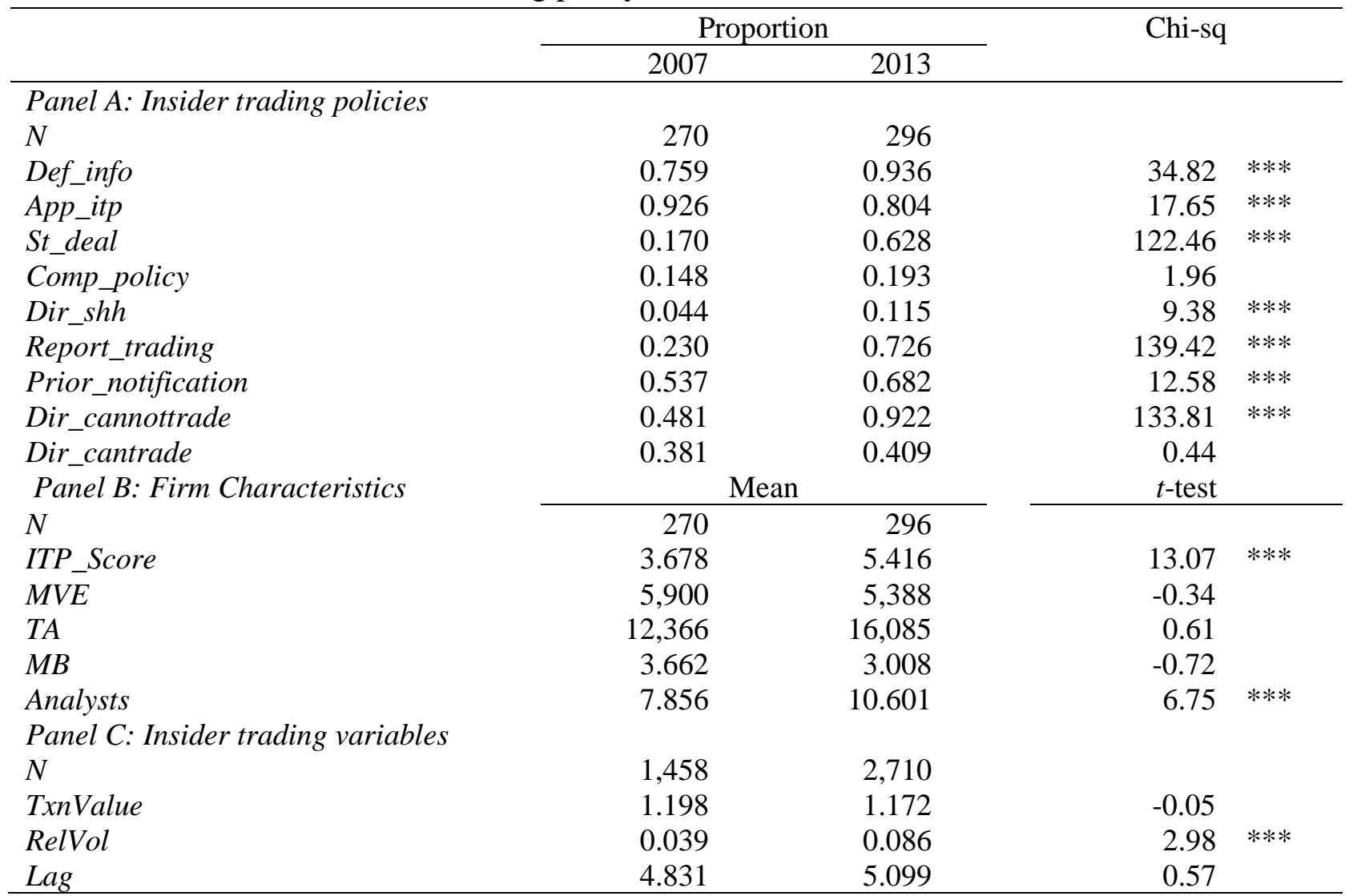

Note: The table shows the use of insider trading policy and the categories of items discussed in the policies for firms in the S\&P ASX300 index for years 2007 and 2013. The table reports the proportion of firms with a policy that includes items in the following categories in their policy: definitions of information on which insiders are not allowed to trade and reinforcement of regulation (Def_info), shares and financial products the policy refers to (App_itp), Restrictions on short term dealing (St_dealing), awareness and monitoring of compliance with policy (Comp_policy), details of director shareholding requirements (Dir_shh), reporting of trading (Report_trading), prior notification/approval of trading (Prior_notification), windows in which directors cannot trade (Dir_cannottrade), and windows in which directors can trade (Dir_cantrade). The table also reports the mean number of categories (ITP_Score) discussed in the trading policies. $M V E$ is the market capitalisation in $\$$ millions; $T A$ is total assets in $\$$ millions; $M B$ is the market to book ratio and Analysts is the number of analyst following. TxnValue is the transaction value measured as the number of shares traded multiplied by the trade price on the trade date in \$ millions; RelVol is the transaction volume divided by the number of shares outstanding expressed as a percentage. Lag is the number of days between the trade date and the date the trade is reported to the Exchange 


\section{Table 2}

Regressions of insider trading policy on firm characteristics

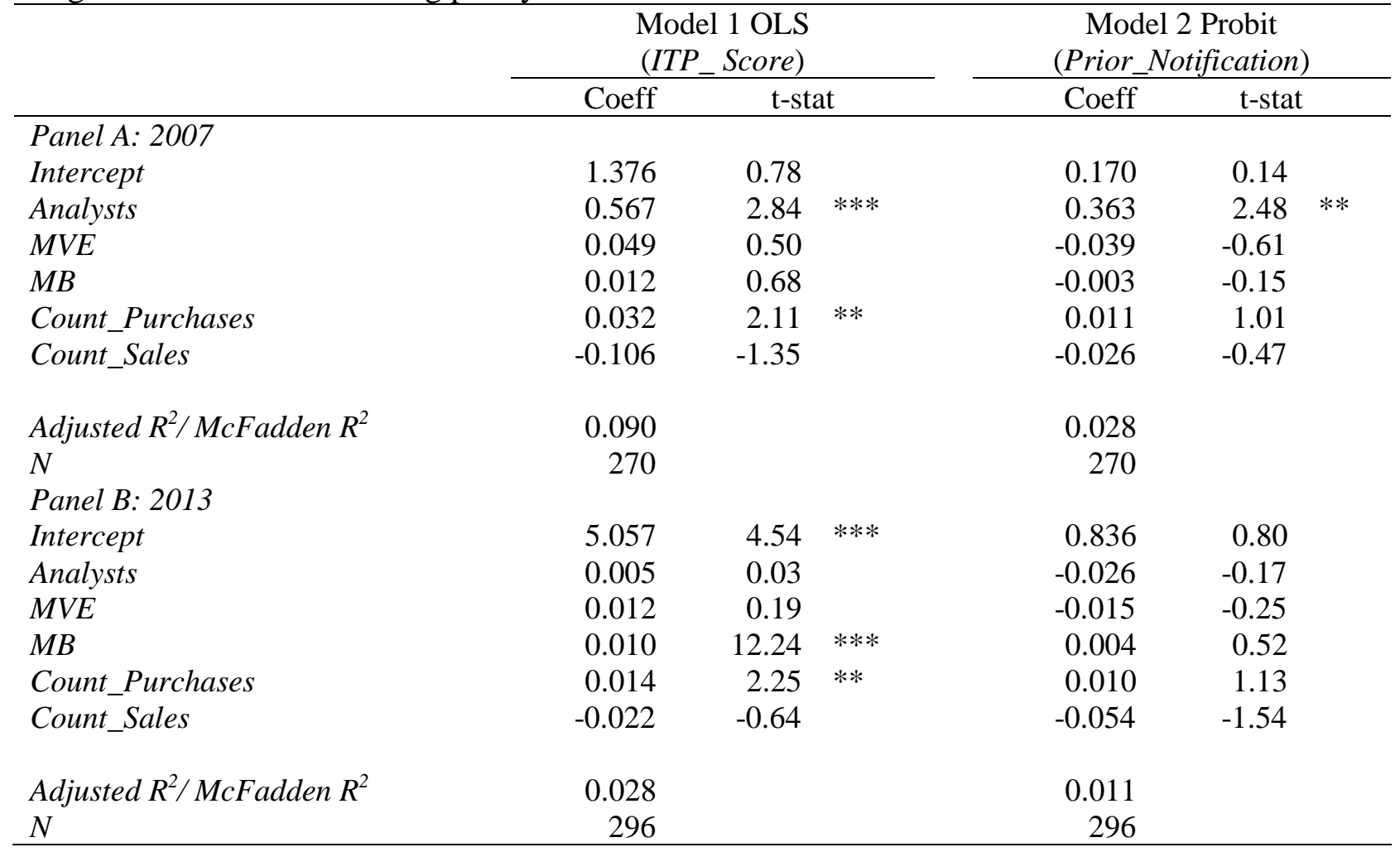

Note: Model 1 is an ordinary least squares model with the ITP_Score as the dependent variable. ITP_Score is the number of categories discussed in the trading policy. Model 2 is a probit model where the dependent variable is the binary variable Prior_Notification which takes the value of one if the policy specifies that prior notification is to be given before the insider could trade and zero otherwise. Analysts is the number of analyst following. $M V E$ is the market capitalisation in $\$$ millions. $M B$ is the market to book ratio and Count is the number of insider trades conducted during the year. ***, **, and * denote statistical significance at the $1 \%, 5 \%$ and $10 \%$ (two-tail) levels, respectively. 
Table 3

Regressions of frequency of insider trades on insider trading policy and firm characteristics

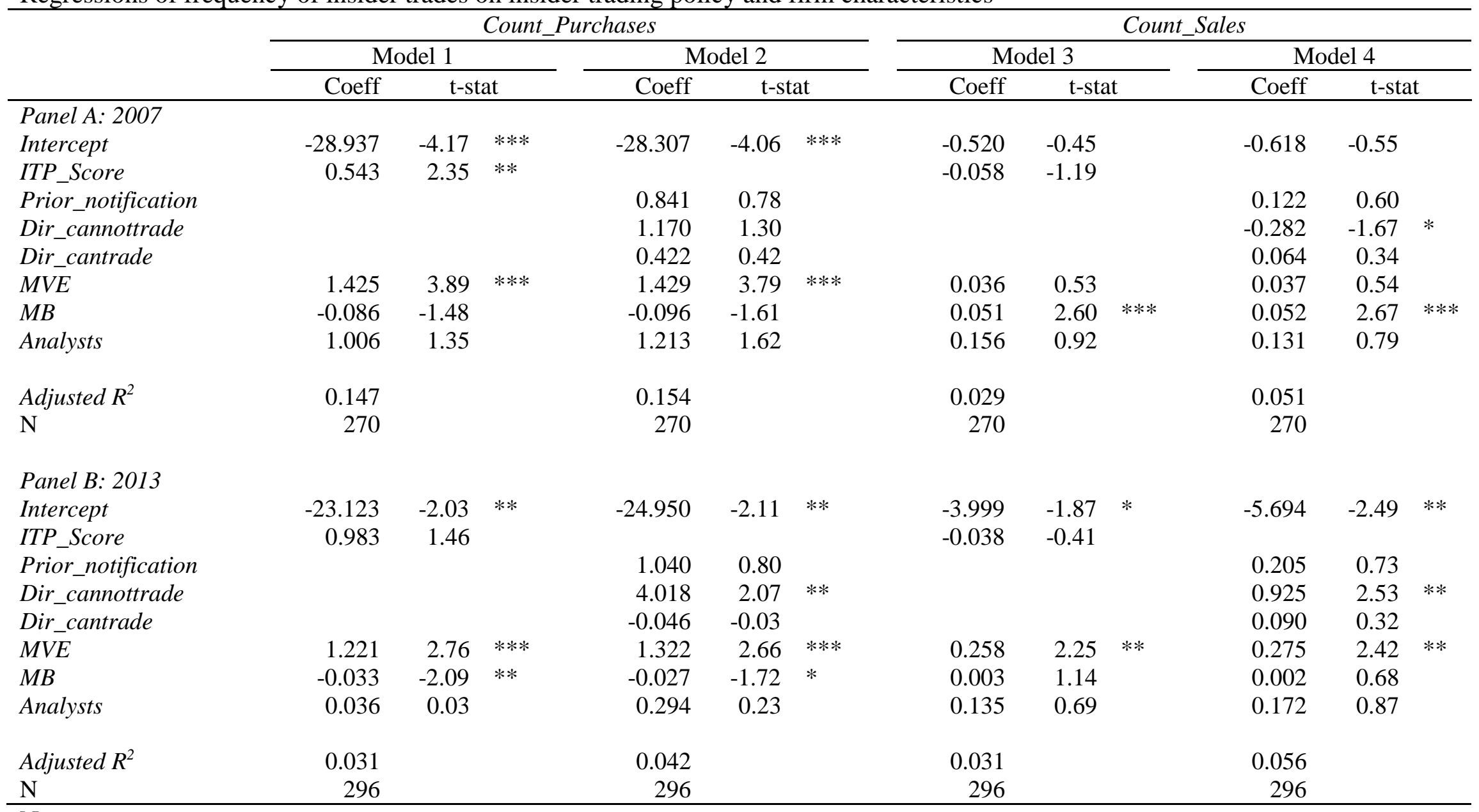

Note: The dependent variable, Count, is the number of insider trades during the year. ITP_Score is the number of categories discussed in the trading policy. Prior_Notification which takes the value of one if the policy specifies that prior notification is to be given before the insider could trade and zero otherwise. Dir_cannottrade (Dir_cantrade) is a dummy variable that takes the value of one if the policy specifies windows in which directors cannot (can) trade and zero otherwise. Analysts is the number of analyst following. MVE is the market capitalisation in \$ millions. $M B$ is the market to book ratio. ***, **, and * denote statistical significance at the $1 \%, 5 \%$ and $10 \%$ (two-tail) levels, respectively. 


\section{Table 4}

Cumulative abnormal returns on insider trades in different windows

\begin{tabular}{|c|c|c|c|c|}
\hline & $\mathrm{N}$ & $\operatorname{CAR}(0,+5)$ & $\operatorname{CAR}(0,+10)$ & $\operatorname{CAR}(0,+20)$ \\
\hline \multicolumn{5}{|c|}{ Panel A: 2007 Insider trading profits in different windows } \\
\hline All & 1,458 & 0.330 & 0.560 & -0.050 \\
\hline Blackout (BO) & 5 & -0.787 & -1.726 & -3.078 \\
\hline Permitted $(\mathrm{P})$ & 362 & 0.118 & 0.295 & -0.842 \\
\hline Unclassified (U) & 1,091 & 0.408 & 0.656 & 0.228 \\
\hline$t$-test (BO versus $\mathrm{P})$ & & -0.43 & -1.20 & -1.63 \\
\hline$t$-test (BO versus $\mathrm{U}$ ) & & -0.57 & -1.42 & $-2.42 *$ \\
\hline$t$-test (P versus $\mathrm{U})$ & & -1.22 & -1.22 & $-2.59 * * *$ \\
\hline \multicolumn{5}{|c|}{ Panel B: 2013 Insider trading profits in different windows } \\
\hline All & 2,710 & 0.240 & 0.270 & 0.620 \\
\hline Blackout (BO) & 249 & 1.436 & 1.353 & 1.134 \\
\hline Permitted $(\mathrm{P})$ & 529 & 0.172 & 0.281 & 1.011 \\
\hline Unclassified (U) & 1,932 & 0.110 & 0.129 & 0.443 \\
\hline$t$-test (BO versus $\mathrm{P}$ ) & & $2.71 * * *$ & 1.65 & 0.17 \\
\hline$t$-test (BO versus $\mathrm{U}$ ) & & $3.08 * * *$ & $2.05 * *$ & 1.04 \\
\hline$t$-test (P versus $\mathrm{U})$ & & 0.22 & 0.39 & 1.11 \\
\hline
\end{tabular}

Note: Cumulative abnormal returns, in percent, are the cumulative market adjusted returns where day 0 is the trade date. Abnormal returns are computed for each trade using the market model estimated over the period $(-110,-10)$ where day 0 is the trade date. Blackout (Permitted) windows are specified by firms as periods where insiders are prohibited from trading (permitted to trade). Unclassified windows are periods that have not been specified by firms as periods where trading could or could not occur. ***, **, and * denote statistical significance at the $1 \%, 5 \%$ and $10 \%$ (two-tail) levels, respectively. 


\section{Table 5}

Regressions of cumulative abnormal returns on trading restrictions

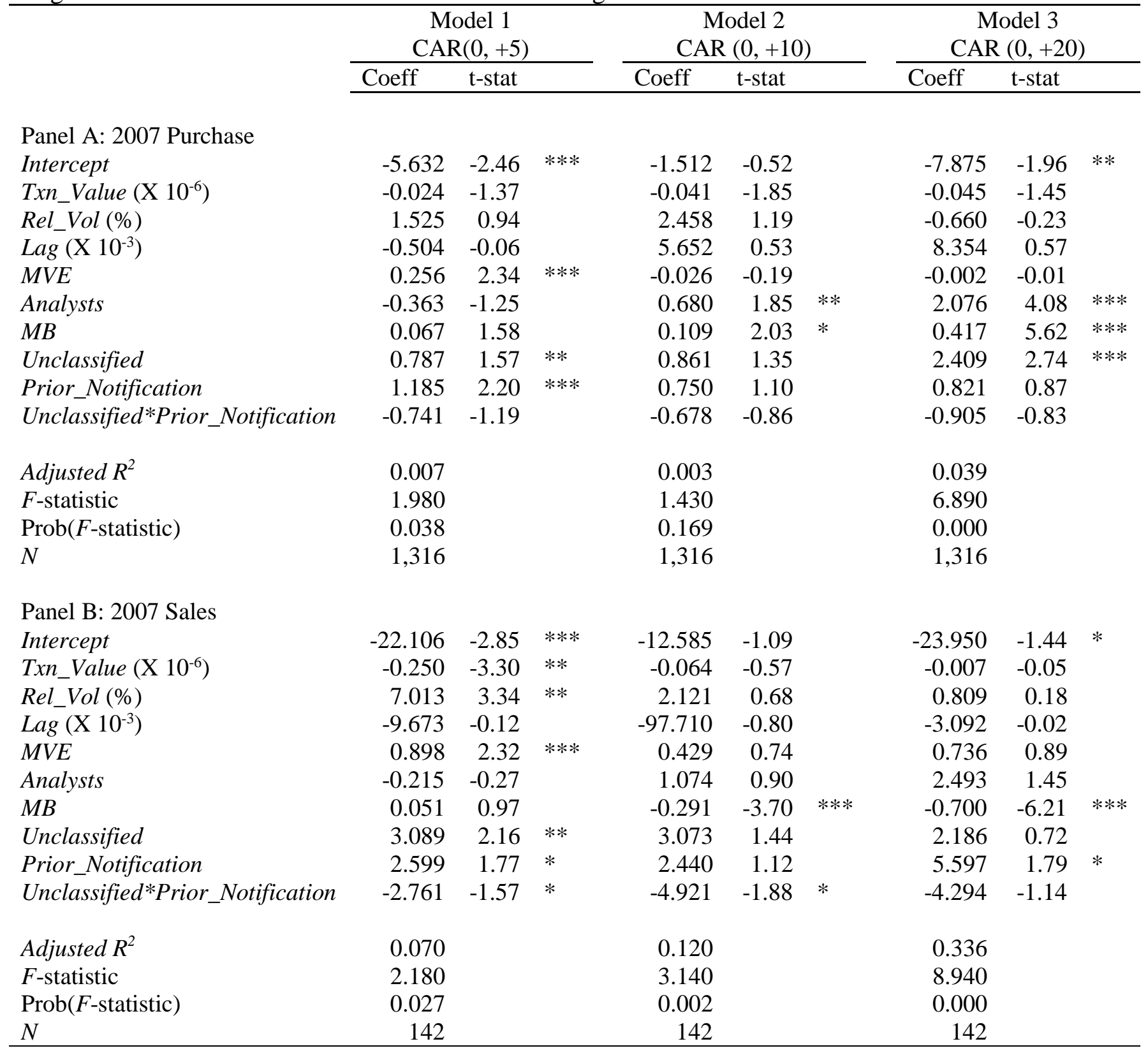




\begin{tabular}{|c|c|c|c|c|c|c|c|c|c|}
\hline & \multicolumn{3}{|c|}{$\begin{array}{c}\text { Model 1 } \\
\text { CAR }(0,+5)\end{array}$} & \multicolumn{3}{|c|}{$\begin{array}{c}\text { Model } 2 \\
\text { CAR }(0,+10)\end{array}$} & \multicolumn{3}{|c|}{$\begin{array}{c}\text { Model } 3 \\
\text { CAR }(0,+20)\end{array}$} \\
\hline & Coeff & t-stat & & Coeff & t-stat & & Coeff & t-stat & \\
\hline Panel C: 2013 Purchases & & & & & & & & & \\
\hline Intercept & -0.998 & -0.75 & & -1.157 & -0.64 & & -0.028 & -0.01 & \\
\hline Txn_Value $\left(\mathrm{X} 10^{-6}\right)$ & -0.084 & -1.21 & & 0.040 & 0.42 & & 0.069 & 0.56 & \\
\hline Rel_Vol $(\%)$ & 1.575 & 2.05 & $*$ & -0.262 & -0.25 & & -0.217 & -0.16 & \\
\hline $\operatorname{Lag}\left(\mathrm{X} \mathrm{10^{-3 }}\right)$ & -7.066 & -0.75 & & -14.296 & -1.10 & & -36.951 & -2.20 & \\
\hline$M V E$ & 0.108 & 1.70 & $* * *$ & 0.083 & 0.95 & & 0.151 & 1.33 & \\
\hline Analysts & -0.474 & -1.86 & & -0.333 & -0.96 & & -1.211 & -2.68 & $* *$ \\
\hline$M B$ & 0.007 & 0.68 & & 0.009 & 0.60 & & 0.016 & 0.84 & $* *$ \\
\hline Unclassified & -0.214 & -0.35 & & -0.318 & -0.38 & & -0.711 & -0.65 & \\
\hline Blackout & 1.607 & 1.81 & $*$ & 3.594 & 2.95 & $* * *$ & 4.201 & 2.66 & $* * *$ \\
\hline Prior_Notification & 0.361 & 0.54 & & 0.825 & 0.91 & & 1.548 & 1.31 & \\
\hline Unclassified*Prior_Notification & -0.376 & -0.50 & & -0.261 & -0.25 & & -0.793 & -0.59 & \\
\hline Blackout*Prior_Notification & -0.702 & -0.62 & & -3.111 & -2.01 & $* *$ & -5.599 & -2.79 & $* * *$ \\
\hline Adjusted $R^{2}$ & 0.005 & & & 0.003 & & & 0.008 & & \\
\hline$F$-statistic & 2.060 & & & 1.700 & & & 2.620 & & \\
\hline $\operatorname{Prob}(F$-statistic $)$ & 0.020 & & & 0.068 & & & 0.003 & & \\
\hline$N$ & 2,267 & & & 2,267 & & & 2,267 & & \\
\hline Panel D: 2013 Sales & & & & & & & & & \\
\hline Intercept & 6.447 & 2.85 & $* * *$ & 9.373 & 2.88 & $* *$ & 15.654 & 2.78 & $* *$ \\
\hline Txn_Value (X 10-6) & 0.002 & 0.18 & & 0.004 & 0.29 & & 0.009 & 0.36 & \\
\hline Rel_Vol $(\%)$ & -0.142 & -0.35 & & -0.592 & -1.00 & & -0.947 & -0.93 & \\
\hline $\operatorname{Lag}\left(X 10^{-3}\right)$ & 24.969 & 1.65 & & 84.542 & 3.89 & $* *$ & 182.199 & 4.85 & ** \\
\hline$M V E$ & -0.262 & -2.48 & $* * *$ & -0.328 & -2.15 & $*$ & -0.504 & -1.91 & \\
\hline Analysts & -0.831 & -1.37 & & -1.345 & -1.54 & $*$ & -2.146 & -1.42 & \\
\hline$M B$ & -0.008 & -0.52 & $*$ & 0.000 & 0.01 & & -0.034 & -0.89 & $* * *$ \\
\hline Unclassified & 1.065 & 1.20 & & 0.414 & 0.32 & & 0.694 & 0.31 & \\
\hline Blackout & 2.438 & 1.04 & & 1.343 & 0.40 & & 0.873 & 0.15 & \\
\hline Prior_Notification & 2.300 & 2.29 & $* *$ & 3.131 & 2.16 & $* *$ & 3.670 & 1.47 & $*$ \\
\hline Unclassified $*$ Prior_Notification & -1.153 & -0.93 & & -1.073 & -0.60 & & -2.225 & -0.72 & \\
\hline Blackout*Prior_Notification & -3.224 & -1.19 & & -6.599 & -1.70 & $* *$ & -9.309 & -1.39 & $* *$ \\
\hline Adjusted $R^{2}$ & 0.038 & & & 0.071 & & & 0.068 & & \\
\hline$F$-statistic & 2.580 & & & 4.050 & & & 3.950 & & \\
\hline $\operatorname{Prob}(F$-statistic $)$ & 0.004 & & & 0.000 & & & 0.000 & & \\
\hline$N$ & 443 & & & 443 & & & 443 & & \\
\hline
\end{tabular}

Note: Txn_Value is the transaction value measured as the number of shares traded multiplied by the trade price; Rel_Vol is the transaction volume divided by the total number of shares outstanding as at the end of the financial year; Lag is the lag between the trade date and the date the trade is reported to the Exchange; $M V E$ is the natural logarithm of the market capitalisation at the beginning of the year; Analysts is the number of analyst following; $M B$ is the market to book ratio at the beginning of the year; Blackout (Permitted) windows are specified by firms as periods where insiders are prohibited from trading (permitted to trade) and zero otherwise. Unclassified windows are periods that have not be specified by firms as periods where trading could or could not occur. Prior_Notification which takes the value of one if the policy specifies that prior notification is to be given before the insider could trade and zero otherwise. $* * *, * *$, and $*$ denote statistical significance at the $1 \%, 5 \%$ and $10 \%$ (two-tail) levels, respectively. 


\begin{tabular}{|c|c|}
\hline Policy category & Examples of items within the category \\
\hline Def_info & $\begin{array}{l}\text { - } \quad \text { Cannot trade on price sensitive information } \\
\text { - Cannot trade on price sensitive about other companies }\end{array}$ \\
\hline App_itp & $\begin{array}{l}\text { - } \quad \text { Restrictions apply to trading in company shares } \\
\text { Restrictions apply to trading in financial products created by third } \\
\text { parties }\end{array}$ \\
\hline St_deal & $\begin{array}{l}\text { - } \quad \text { Directors must not undertake short term dealing }(<1 \text { year }) \\
\text { Directors must not undertake short term dealing in related } \\
\text { securities }(<1 \text { year) }\end{array}$ \\
\hline Comp_policy & $\begin{array}{l}\text { - Prior to trading, directors must review pre-dealing checklist/ } \\
\text { declaration signed prior } \\
\text { - } \quad \text { Directors must declare annual compliance with policy } \\
\text { - } \quad \text { Penalties for breach in place }\end{array}$ \\
\hline Dir_shh & $\begin{array}{l}\text { - Share trading policy stipulates that managing director can only } \\
\text { deal in company shares } \\
\text { - Share trading policy stipulates directors must hold minimum } \\
\text { Shares } \\
\text { - Non-executive directors must invest } 25 \% \text { of director fees per } \\
\text { Year in company }\end{array}$ \\
\hline Report_trading & $\begin{array}{l}\text { Directors must give details of trade to company secretary/ } \\
\text { company } \\
\text { - } \quad \text { Directors must give details of trade to chair }\end{array}$ \\
\hline Prior_notification & $\begin{array}{l}\text { - } \quad \text { Directors must give prior notice of trade to company } \\
\text { - } \quad \text { Directors must give prior notice of trade to company secretary } \\
\text { - } \quad \text { Director notices reported to audit committee }\end{array}$ \\
\hline Dir_cannottrade & $\begin{array}{l}\text { Directors cannot trade: } \\
\text { - } \quad 76-90 \text { days prior } \\
\text { - } \quad 61-75 \text { days prior } \\
\text { - } \quad 31-45 \text { days prior } \\
\text { - } \quad 0-24 \text { hours after } \\
\text { - } \quad 25-48 \text { hours after }\end{array}$ \\
\hline Dir_cantrade & 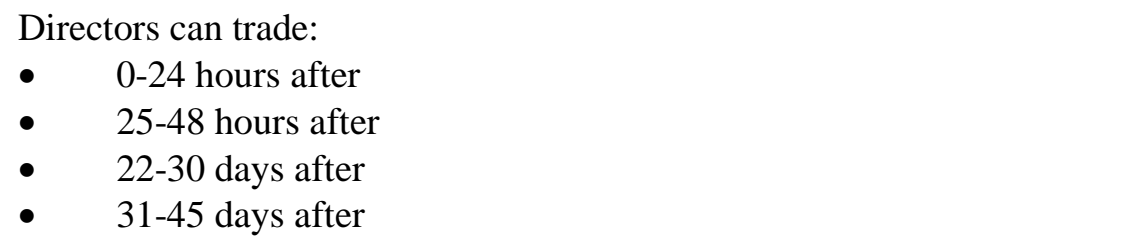 \\
\hline
\end{tabular}

